\title{
THE BEAUTY OF HOLINESS: HOLY ICONS AS SPIRITUAL EDUCATION
}

Mark J. CHERRY*

\begin{abstract}
The deep beauty of holy icons is not attached primarily to the skill of the artist, but rather to the proper disclosure of the truths that they reveal. Written correctly, holy icons form a central component of Orthodox Christian theology, locating persons within Traditional Christian understandings of God, His saints and the Church. Icons provide both spiritual orientation and education regarding Christianity's core metaphysical, epistemological, historical, and spiritual understandings. Wrongly written icons, modernistic and expressionistic paintings, fail in this regard; truth is distorted by the desires of the artist. This presentation briefly explores five dimensions about which holy icons provide instruction, situating canonical understandings regarding the nature of reality and of our place within that reality: (1) the relation of persons to the world; (2) the relation of persons to animals; (3) the proper relationship among living humans; (4) the relation among humans over time; (5) the relation between persons and God. Readers are put on notice, however, that this analysis of icons necessarily truncates the phenomena it analyzes. Holy icons are set within lived experiential ritual practices, interacting with reality in facets beyond the ability of academic discursive analysis to conceptualize. It is by praying with holy icons that we truly come to appreciate the ways in which they embody canonical understandings regarding the nature and meaning of the cosmos and of man's place within it.
\end{abstract}

Keywords: Orthodox Christian Epistemology, Icons, Rituals

\section{Introduction: Holy Icons and the Ritual Lives of Christians}

The deep beauty of holy icons is not attached primarily to the

* Professor, St. Edward's University (Department of Philosophy), Austin, Texas, USA. 
skill of the artist, but rather to the proper disclosure of the truths that they reveal. Written correctly, holy icons form a central component of Orthodox Christian theology, locating persons within Traditional Christian understandings of God, His saints and the Church. Icons provide both spiritual orientation and education regarding Christianity's core metaphysical, epistemological, historical, and spiritual understandings. Wrongly written icons, modernistic and expressionistic paintings, utterly fail in this regard; artistic desires distort Christian truth. This presentation briefly explores five dimensions about which holy icons provide instruction, situating canonical understandings regarding the nature of reality and of our place within that reality. Readers are put on notice, however, that this analysis of icons necessarily truncates the phenomena it analyzes. The religious role of holy icons is set within lived experiential ritual practices, interacting with reality in facets beyond the ability of academic discursive analysis to conceptualize. As I will argue, icons play an essential role in the ritual lives of Christians. It is by praying with holy icons that we truly come to appreciate the ways in which they embody canonical understandings regarding the nature and meaning of the cosmos and of man's place within it. Icons both announce and educate regarding the place of man within nature, proper relationships within families, as well as the appropriate relationship between man and God, as they reveal how, with whom, and to Whom to pray.

\section{Holy Icons and Christian Epistemology}

Traditional Christian epistemology is nested within the cardinal ritual practices of prayer and worship. It is through right worship that Christians seek and come to know Truth, where Truth is not a "what" but a Who: the one God. To know truly one must correctly orient oneself towards God and come to know Him. Christians recognize that this is a relationship among real persons: between finite humans and the transcendent God. The traditional ascetic practices (e.g., prayer, fasting, almsgiving) aid in the development of spiritual discipline, as one learns to set aside one's own passions and desires so as to acquire a will in union with God. The process of repentance, forgiveness, and illumination must be experienced to be known. 
As a result, the center of the Christian spiritual life must be embodied in right ritual, right worship, so as to be properly oriented towards God and to enter into relationship with Him. The central epistemic vantage point is not found within philosophy, but rather in the union of the Orthodox Christian assembly in the Divine Liturgy, where liturgical prayer involves the mystical union of the community with God. Rightly oriented worship is central to sustaining traditional Christian belief and culture. It connects cosmic history and human achievement with God and the deep nature of reality. As the Second Council of Nicaea in AD 787 confirmed, venerating holy icons is a core element of Orthodox prayer and worship. Icons embed Christians within powerful and illuminating learning experiences: they communicate meaning, teaching God's commands, illustrating the history of salvation, and binding Christian communities through time and space.

The Council recognized that properly written icons proclaim the truth of Christ as fully God and fully man, teach the narrative and lessons of the Gospel, and illuminate key elements of the lives of the most Holy Theotokos, the Angels, and the Saints. The Council held that:

These honourable and venerable images ...we honour and salute and reverently venerate: to wit, the image of the incarnation of our great God and Saviour Jesus Christ, and that of our spotless Lady the all-holy Mother of God, from whom he pleased to take flesh, and to save and deliver us from all impious idolatry; also the images of the holy and incorporeal Angels, who as men appeared to the just. Likewise also the figures and effigies of the divine and all-lauded Apostles, also of the God-speaking Prophets, and of the struggling Martyrs and of holy men. So that through their representations we may be able to be led back in memory and recollection to the prototype, and have a share in the holiness of some one of them ${ }^{1}$.

Icons are not honored or venerated simply for their own $\mathrm{sake}^{2}$. St. John of Damascus (c. 676-749) reminds us that the honor and veneration

$1 * * *$ The seventh ecumenical council - The second council of Nicaea (787). In Nicene and Post-Nicene Fathers, Philip Schaff and Henry Wace (eds.), vol. 14, second series. Peabody, Hendrickson Publishers, 2004, p. 541.

2 This is a point thoroughly misunderstood by the authors of the Libri Carolini. See Richard C. DALES, The Intellectual Life of Western Europe in the Middle Ages, New York, E. J. Brill, 1995, p. 87. 
given the icon passes over to that which is imaged, to God and His saints.

Of old, God the incorporeal and uncircumscribed was never depicted. Now, however, when God is seen clothed in flesh, and conversing with men, I make an image of the God whom I see. I do not worship matter, I worship the God of matter, who became matter for my sake, and deigned to inhabit matter, who worked out my salvation through matter. I will not cease from honouring that matter which works my salvation. I venerate it, though not as God. ... I honour all matter besides, and venerate it. Through it, filled, as it were, with a divine power and grace, my salvation has come to me. ${ }^{3}$

St. John argues that God Himself has blessed each of the lifegiving elements of our salvation: from the blessed wood of the Cross, the sacred mountain of Calvary, the Holy Sepulchre, and the Gospels, to the blessed altar, "which give us the Bread of Life", and the crosses, altar plates and chalices. Moreover, as he notes: "And before all these things, is not the body and blood of our Lord matter? Either do away with the veneration and worship due to all these things, or submit to the tradition of the Church in the worship of images, honouring God and His friends, and following in this the grace of the Holy Spirit" ${ }^{\text {". To see }}$ truly, one must already have an idea of what truth is and how to find it. Icons orient us through pictures towards the concepts and categories necessary appropriately to encounter and to know the world. Proper prayer and religious education tutor Orthodox Christians regarding how to orient correctly towards God. Given time and proper habituation, one is taught about the persons and events central to the history of salvation, as well as how rightly to see the world.

Wrongly oriented prayer and incorrectly written icons fail in this regard. False religious imagery distorts Christian worship and is

3 "For as Basil (the Great, c. 330-379), that much-versed expounder of divine things, says, the honour given to the image passes over to the prototype. Now a prototype is that which is imaged, from that which the derivative is obtained", St. John of DAmascus, "Exposition of the Orthodox Faith", trans. S.D.F. Salmon in Nicene and Post Nicene Fathers, $2^{\text {nd }}$ Series, repr. Grand Rapids MI, Wm. B. Eerdmans, 1955, Vol IX, p. 88.

${ }^{4}$ St. John Damascene, On Holy Images, trans. Mary H. Allies, London, Thomas Baker, 1898, p. 17. 
spiritually harmful. "Feminist rituals" of goddess worship and witchcraft are easily seen as diabolical ${ }^{5}$. Modernistic or post-modern Christian art are often more subtle but can be similarly problematic in inviting a private interpretation of who God is and what He commands. Such art may display the talents of the artist, but they fail properly to capture Orthodox truths. Moreover, religious images are often used to signal changes in underlying religious understandings. Here, one might consider the attempts of various Protestant religions to create positive images of homosexual marriage, publicizing pictures and paintings of same-sex marriages, as well as of the ordination of active homosexuals and lesbians as priest and bishops. (Episcopalians, Methodoists, and Lutherans accept the ordination of priestesses. In 2015, the Presbyterian Church USA voted to accept same sex marriage.) Distorting the traditional rituals and images of Christian life and worship makes it difficult to discern good from evil undistorted by desire ${ }^{6}$. Progressive proponents fully appreciate the very powerful role of such nontraditional imagery to shift underlying moral and spiritual understandings and thereby to change their religions ${ }^{7}$.

\section{Icons and Ritual Disclosure: Five Dimensions of Reality}

${ }^{5}$ Kathryn RoundtreE, Embracing the Witch and the Goddess: Feminist Ritual-Makers in New Zealand, New York, Routledge, 2004.

6 This is why St. Makarios of Egypt (A.D. 331-391) reminds us: "Most people, however, are exactly like men walking at night wholly without light and not enjoying the slightest illumination in their souls from the divine Logos, so that they scarcely differ from the blind. They are totally caught up in material entanglements and the chains of temporal life, neither restrained by divine awe nor performing any virtuous acts... those who live in the world and are illumined by the holy commandments as by the stars, and who do cleave to God with faith and awe, are not utterly shrouded in darkness and for this reason can hope to attain salvation", St. Makarios of Egypt, "The Freedom of the Intellect", in The Philokalia, eds. G.E.H. Paler, Philip Sherrard and Kallistos Ware, (337-354), London, Farber and Farber, 1986, p. 350.

${ }^{7}$ Lutheran scholar Jillian Cox argues that the morality of homosexual acts should be rethought in terms of "...a contemporary notion of committed, egalitarian, lesbian and gay relationships" (2013, p. 369). Homosexual acts advocates conclude should not be understood as sinful and Christianity ought to bless homosexual marriage; J. Cox, „The only safe guide is love”: Models of engaging Luther's ethical hermeneutic for theological responses to the affirmation of same-sex sexuality, in A Journal of Theology (52) no.4/2013, p. 365-372. 
Gazing upon icons and praying with them calls us into the liturgical life of the Orthodox Church. As a result, "The iconographer's first concern is not to make himself known but to proclaim God's kingdom through his art. Icons are meant to have a place in the sacred liturgy and are thus painted in accordance with the demands of the liturgy" 8 . Written correctly, these sacred images educate Christians regarding the presence of intimates, friends, or strangers, proper relationships within families and social groups, as well as of the boundaries between the holy, the diabolical, and the profane. As part of our prayer life, holy icons situate canonical understandings regarding the nature of reality and of our place within that reality. Consider five dimensions of such instruction:

1) Icons reveal the proper relation of persons to the world. Icons locate humans within the cosmos, within nature, announcing God as Creator and as at the center of reality. Here, consider icons which depict Christ's giving sight to the blind or raising Lazarus from the dead. In giving sight to the man who was blind from birth, the Gospel of John reports that Christ "spat on the ground and made clay with the saliva; and He anointed the eyes of the blind man with the clay" (John 9: 6). Commenting on this passage, St. Irenaeus (c. 120-202 AD) argues that Jesus revealed His Deity by restoring part of the creation of the world:

For as the scripture says, He made [man] by a kind of process: "And the Lord took clay from the earth, and formed man." Wherefore also the Lord spat on the ground and made clay, and smeared it upon the eyes, pointing out the original fashioning [of man], how it was effected, and manifesting the hand of God to those who can understand by what [hand] man was formed out of the dust. ... He then supplied in public, that the works of God might be manifested in him....

Icons depicting the raising of Lazarus from the dead often show Lazarus's sisters, Mary and Martha, at Christ's feet, with the apostles in the background. As Jesus said to Martha: "I am the resurrection and the life. He who believes in Me, though he may die, he shall live. And

${ }^{8}$ Henri Nouwen, Behold the Beauty of the Lord: Praying with Icons, Ave Maria Press, Notre Dame, 1987, p. 14.

9 St. Irenaeus, "Against Heresies", in Ante-Nicene Fathers vol. 1, eds. Alexander Roberts and James Donaldson, Peabody, Hendrickson Publishers, 2004, p. 543. 
whoever lives and believes in Me shall never die" (John 11: 25-26). Christ's miraculous raising of Lazarus from the dead is a reassurance to His disciples that while He will suffer and die, He is the Lord of life and death. It thereby foreshadows Christ's own resurrection and anticipates the resurrection of the righteous on the last day ${ }^{10}$. Such icons depict central elements of the Gospel, while locating humans firmly within God's Creation.

2) Icons reveal the proper relation of persons to animals. Icons teach Christians regarding the hierarchical nature of God's creation. For example, icons depict Adam naming the animals. Such icons often begin with the creation of Adam, reminding us that we also are God's creation. As the animals then come forth, Adam names each according to their natures, and Christ gives His blessing to them, illustrating Genesis 2:19: "Now the Lord God had formed out of the ground all the wild animals and all the birds of the sky. He brought them to the man to see what he would name them; and whatever the man called each living creature, that was its name." Such icons implicitly denounce the antiChristian call to understand animals as equal to humans ${ }^{11}$; instead, these icons vividly capture the dominion of humans over nature. Again, consider Genesis: "Then God said, 'let us make mankind in our image, in our likeness, so that they may rule over the fish in the sea and the birds in the sky, over the livestock and all the wild animals, and over all the creatures that move along the ground" (1:27). Moreover, since

${ }^{10}$ See http:// lent. goarch.org/saturday_of_lazarus/learn (accesed on 14.04.2017).

11 The "biocentric viewpoint", for example, requires humans to regard themselves as simply one member among others of the earth's community. Human good matters, but only in the same terms as the good of non-human members of the ecosphere. Humans are not to appreciate themselves as superior, but only as equal members. "Biocentric equality is intimately related to the all-inclusive Self-realization in the sense that if we harm the rest of Nature then we are harming ourselves. There are no boundaries and everything is interrelated. But insofar as we perceive things as individual organisms or entities, the insight draws us to respect all human and nonhuman individuals in their own right as parts of the whole without feeling the need to set up hierarchies of species with humans at the top"; Bill DEvall and George Sessions, "Deep ecology", in D. Van DeVeEr, C. PIERCE (eds.), The Environmental Ethics \& Policy Book (p. 263-267), Belmont,Wadsworth/Thomson, 2003, p. 265. Paul TAYLOR, "The ethics of respect for nature", in D. Van DEVEER, C. PIERCE (eds.), The Environmental Ethics \& Policy Book, Belmont, CA, Wadsworth/Thomson, 2003, p. 201-214. 
Adam had not yet fallen through disobedience into sin, he is shown naked and unashamed (Genesis 2:25). Icons work synergistically with Christian prayers that similarly recognize and teach the hierarchical nature of God's creation. Consider, for example, the expression given to man's place in creation in the ritual blessing of flesh meats at Pascha.

3) Icons reveal the proper relationship among living humans. Icons demonstrate how we ought to live. Consider, for example, icons of the Wedding at Cana, which show the closeness of the relationship between Christ and His mother, as well as the importance of the marriage of man and woman. The marriage ceremony publically announces a change in social, moral, and spiritual reality: man and woman have become husband and wife. Icons of Saints Joachim and Anna (the Theotokos' parents) often depict them standing in a tender and loving embrace, beautifully illustrating the intimate relationship of husband and wife. Such icons set out the traditional marriage of man and woman, as well as family life, as a normative form of social being, a regulative category of social life, expressive of the proper form of human flourishing. In the Christian family, there is the recognition and affirmation of the normative authority of a stable union of husband and wife, united in Holy Matrimony. Such icons provide a regulative ideal over against which actual instances of the family are measured and toward which families and their members are obliged to strive ${ }^{12}$.

4) Icons reveal the relation among humans over time. Icons capture the central theology of important feast days of the Church (such as the Annunciation, the Nativity, Passion, and Resurrection). As a result, icons function as part of the liturgical calendar that regulates the life of the Church, mystically integrating the lives of contemporary Christians with the lives of Christ, the Theotokos, and the saints. Icons of the saints, for example, illustrate key moments in their lives. Consider the icon of St. John the Forerunner, which often depicts him holding his head on a platter, vividly demonstrating his martyrdom ${ }^{13}$. Marking the

12 See Mark J. Cherry, Sex, Family, and the Culture Wars, New Brunswick, Transaction Publishers, 2016.

${ }^{13}$ As the Second Council at Nicaea in 787 stated: "[We have also decreed] that the brave deeds of the Saints be portrayed on tablets and on the walls, and upon the sacred vessels and vestments as hath been the custom of the Holy Catholic Church of God from ancient times (op. cit., p. 572). 
feast days of the saints, as well as the fasts and feasts of the Church, icons draw Christians into mystical participation in that life. As an example, consider the celebration on the first Sunday of Great Lent of the triumph of the Church over the Iconoclasts and the reestablishment of the use of icons in worship. Holy icons are carried around the church in solemn procession ${ }^{14}$. Written properly, icons painted today reveal the very same Christian truths as those written in the ancient world ${ }^{15}$. Orthodoxy is but one unchanging and unchangeable faith. Icons remind Christians when, how, with whom, and to Whom to pray. They locate persons within Christian communal time and the history of salvation.

5) The relation between persons and God. Icons also remind us that through right worship Christians seek, come to know, and have a personal relationship with the one God. We must die to ourselves, fully repent and submit to God. Consider, for example, depictions of the tender embrace of the Theotokos and the Christ child. This is not merely a sentimental hug, but the portrayal of the mysterious interaction between God and humanity through the Theotokos ${ }^{16}$. Icons also capture the central reality of the holiness of saints: the halos of the saints reflect the uncreated light of grace that shines within them ${ }^{17}$. Consider also the

14 After the procession, in the Antiochian Orthodox Christian Archdiocese in North America, the whole parish says together: "As the prophets beheld, as the Apostles have taught,... as the Church has received... as the teachers have dogmatized,... as the Universe has agreed,... as Grace has shown forth,... as Truth has revealed,... as falsehood has been dissolved,... as Wisdom has presented,... as Christ Awarded,... thus we declare,... thus we assert,... thus we preach Christ our true God, and honor as Saints in words, in writings, in thoughts, in sacrifices, in churches, in Holy Icons; on the one hand worshipping and reverencing Christ as God and Lord; and on the other hand honoring as true servants of the same Lord of all and accordingly offering them veneration. This is the Faith of the Apostles, this is the Faith of the Fathers, this is the Faith of the Orthodox, this is the Faith which has established the Universe." http://www.antiochian.org/sundayoforthodoxy (accessed on 14.04.2017)

15 "In contrast to the more familiar art of the West, icons are made according to age-old rules. Their forms and colors depend not merely upon the imagination and taste of the iconographer, but are handed down from generation to generation in obedience to venerable traditions." NouwEN, op. cit., p. 14.

${ }^{16}$ NOUWEN, op cit., p. 40.

17 Archimandrite EPHRAIM, "Preface" to Monastic Wisdom: The Letters of Elder Joseph the Hesychast, St. Anthony's Greek Orthodox Monastery, Florence Arizona, 1998, p. 23. 
Paschal icon, which shows the resurrected Christ pulling Adam and Eve out of the tomb and into heaven. Other righteous (e.g., King David and King Solomon) that have been in the realm of death are shown as waiting for Christ so as to go into heaven. Christ stands over the broken doors of Hades, gripping Adam and Eve by the wrist as one would hold a slave. They are now to be slaves of God in Paradise, rather than slaves to sin and death.

The center of the spiritual life must be embodied in right ritual and right worship so as to be properly oriented towards God and to enter into relationship with Him. We bow before icons, and kiss them, showing love, devotion, and submission to God. For example, when we bow before an icon of Christ, and kiss it, we show submission to and love for God Himself. As central elements of Orthodox Christian ritual worship rightly written icons properly orient believers towards God. Given time and proper habituation, holy icons help teach us how rightly to see the world, to experience God's creation, and how to come to know Him. Icons teach the history of and theology of the Church, providing ongoing experiential instruction.

\section{Conclusion}

As noted, rightly oriented and guided, Christian ritual practices, such as Orthodox prayer and use of icons, are spiritually therapeutic. One engages in actions that change one self and lead one closer to God, treating the soul and curing the effects of sin so that one can learn to judge rightly. St. Isaac the Syrian (A.D. seventh century) likens this process of coming to know to possessing two types of sight: the view of physical objects and the vision of spiritual perception.

What the bodily eyes are to sensory objects, the same is faith to the eyes of the intellect that gaze at hidden treasures. Even as we have two bodily eyes, we have two eyes of the soul, as the Fathers say; yet both have not the same operation with respect to divine vision. With one we see the hidden glory of God which is concealed in the nature of things; that is to say, we behold His might, His wisdom, and His eternal providence for us which we understand by the magnitude of His governance on our behalf. With this same eye we also behold the glory of His holy nature. When God is pleased to admit us to spiritual 
mysteries, He opens wide the sea of faith in our minds ... (Homily 46) ${ }^{18}$.

The intellect is spiritual perception that is conditioned to receive the faculty of divine vision, even as the pupils of the bodily eyes in which sensible light is poured. Noetic vision is natural knowledge that is used [by power] to the natural state and it is called natural light (Homily $66)^{19}$.

Holy icons play an essential role in correctly orienting us towards God, so that we will come to know Him, and through Him to comprehend true human goodness and flourishing.

Holy icons are often referred to as windows into heaven precisely because as part of our prayer life we look through them towards God. They reveal His Divine glory, the reality of His saints and angels; they teach us of God's promises, His mercy, and His judgment. Icons help locate Christians within a very specific relationship with God, properly oriented in time, place and history, in proper relationship with other persons and with God. Icons also reveal those who belong while demarcating those who are outsiders. For non-Orthodox visitors, it can be odd to watch as Orthodox believers enter into the church temple and begin bowing before and kissing icons. For those outside of Orthodox Christianity, traditional icons may appear idiosyncratic, symbolic, or merely aesthetic. Yet, correctly written, holy icons are evocative of the nature of reality itself.

\section{References}

1. *** "The seventh ecumenical council - The second council of Nicaea (787)", in Philip SCHAFF and Henry WACE (eds.), Nicene and Post-Nicene Fathers, vol. 14, second series. Peabody, Hendrickson Publishers, 2004.

2. ChERry, Mark J., Sex, Family, and the Culture Wars, New Brunswick, Transaction Publishers, 2016.

3. Cox, Jilian, "The only safe guide is love": Models of engaging Luther's ethical hermeneutic for theological responses to the

18 St. IsAaC THE SyRIAn, The Ascetical Homilies of Saint Isaac the Syrian, revised second edition, Holy Transfiguration Monastery trans., Boston, Holy Transfiguration Monastery, 2011, p. 223.

${ }^{19}$ Ibidem, p. 323. 
affirmation of same-sex sexuality, in A Journal of Theology (52) no. 4/2013, p. 365-372.

4. DALES, Richard C., The Intellectual Life of Western Europe in the Middle Ages, New York, E. J. Brill, 1995.

5. DeVall, Bill / Sessions, George, "Deep ecology", in D. Van DeVEer / C. PIERCE (eds.), The Environmental Ethics \& Policy Book, Belmont, Wadsworth/Thomson, 2003, p. 263-267.

6. EPHRAIM, Archimandrite, Preface, Monastic Wisdom: The Letters of Elder Joseph the Hesychast, St. Anthony's Greek Orthodox Monastery, Florence Arizona, 1998.

7. Nouwen, Henri, Behold the Beauty of the Lord: Praying with Icons, Ave Maria Press, Notre Dame, 1987.

8. RoundTREE, Kathryn, Embracing the Witch and the Goddess: Feminist Ritual-Makers in New Zealand, New York, Routledge, 2004.

9. St. IREnAeus, "Against Heresies", in Ante-Nicene Fathers, vol. 1, Alexander Roberts and James Donaldson (eds.), Peabody, Hendrickson Publishers, 2004.

10. St. IsAaC the Syrian, The Ascetical Homilies of Saint Isaac the Syrian, revised second edition, Holy Transfiguration Monastery trans., Boston, Holy Transfiguration Monastery, 2011.

11. St. John Damascene, On Holy Images, trans. Mary H. Allies, London, Thomas Baker, 1898.

12. ST. JOHN OF DAMASCUS, Exposition of the Orthodox Faith, trans. S.D.F. Salmon in Nicene and Post Nicene Fathers, $2^{\text {nd }}$ Series, vol. IX, repr. Grand Rapids MI, Wm. B. Eerdmans, 1955

13. ST. MAKARIOS of Egypt, "The Freedom of the Intellect", in The Philokalia, G.E.H. Paler, Philip Sherrard and Kallistos Ware (eds.), London, Farber and Farber, 1986, p. 337-354.

14. TAYLOR, Paul, "The ethics of respect for nature", in D. Van DeVeER / C. PIERCE (eds.), The Environmental Ethics \& Policy Book, Belmont, CA, Wadsworth/Thomson, 2003, p. 201-214. 